\title{
Eksplorasi Kebutuhan Pengembangan Bahan Ajar Menulis Deskriptif Berbasis Kearifan Lokal melalui Strategi Fishbone
}

\author{
Need Exploration for Development of Descriptive Writing Teaching Materials Based on \\ Local Wisdom through the Fishbone Strategy
}

\author{
Charlina $^{1, *}$, Elvrin Septyanti ${ }^{2}$, dan Tria Putri Mustika ${ }^{3}$ \\ 1,2,3 Universitas Riau \\ 1,* Correspondence email: charlina@lecturer.unri.ac.id \\ ${ }^{2}$ Email: elvrin.septyanti@1ecturer.unri.ac.id \\ ${ }^{3}$ Email: tria.putri@1ecturer.unri.ac.id
}

Received: 12 Agustus 2020 Revised: 24 Januari 2020 Accepted: 1 Februari 2021

\begin{abstract}
This study explores the need for teaching materials to write descriptive texts based on local wisdom through the Fishbone strategy. The method used is ex post facto with Miles \& Huberman analysis techniques and data collection techniques through questionnaires. The results of the material analysis, the average value was 3.57 with $71 \%$ with three indicators (1) analysis of learning strategy needs on the material averaged 3.52 to $70 \%$, (2) analysis of the need for completeness of teaching materials 3.59 with $71 \%$, and (3) analysis of the need for language rules on the material the average value is 3.69 with $73 \%$. Then for the teaching material analysis, the average value is 3.40 with $68 \%$ with four indicators (1) analysis of the needs of learning strategies in teaching material with an average value of 3.10 with $62 \%$, (2) analysis of the need for availability of teaching material with an average value of 3.41 with $68 \%$, (3) analysis of the need for language principles in teaching material the average value is 3.55 with $71 \%$, and (4) analysis of needs for evaluation of teaching material is 3.53 to $70 \%$. It is categorized as useful but needs to be redeveloped through a fishbone strategy for maximum results to achieve an excellent category in teaching material innovation.
\end{abstract}

Keywords: teaching materials, local wisdom, fishbone

\begin{abstract}
Abstrak: Penelitian ini bertujuan untuk mengeksplor kebutuhan dari bahan ajar menulis teks deskripsi berbasis kearifan lokal melalu strategi fisbone. Metode yang digunakan, yaitu ex post facto dengan teknik analisis Miles \& Huberman dan teknik pengumpulan data melalui angket. Hasilnya pada analisis materi rata-rata nilainya 3,57 dengan $71 \%$ dengan tiga indikator, yaitu: (1) analisis kebutuhan strategi pembelajaran pada materi rata-rata nilainya 3,52 dengan 70\%, (2) analisis kebutuhan kelengkapan materi ajar rata-rata nilainya 3,59 dengan 71\%, dan (3) analisis Kebutuhan kaidah kebahasaan pada materi rata-rata nilainya 3,69 dengan 73\%. Kemudian untuk analisis bahan ajar didapatkan hasil rata-rata nilainya 3,40 dengan 68\% dengan empat indikator, yaitu (1) analisis kebutuhan strategi pembelajaran pada bahan ajar rata-rata nilainya 3,10 dengan 62\%, (2) analisis Kebutuhan ketersediaan bahan ajar rata-rata nilainya 3,41 dengan 68\%, (3) analisis kebutuhan kaidah kebahasaan pada bahan ajar rata-rata nilainya 3,55 dengan 71\%, dan (4) analisis kebutuhan evaluasi bahan ajar, yaitu 3,53 dengan 70\%. Berkategori baik tetapi perlu pengembangan kembali melalui strategi fishbone untuk hasil yang maksimal guna mencapai kategori sangat baik dalam inovasi bahan ajar.
\end{abstract}

Kata kunci: bahan ajar, kearifan lokal, fishbone

To cite this article:

Charlina, Septyanti, E., \& Mustika, T. P. (2021). Eksplorasi Kebutuhan Pengembangan Bahan Ajar Menulis Deskriptif Berbasis Kearifan Lokal melalui Strategi Fishbone. Diglosia: Jurnal Kajian Bahasa, Sastra, dan Pengajarannya, 4(1), 101-114. https://doi.org/10.30872/diglosia.v4i1.105 


\section{A. PENDAHULUAN}

Pengembangan bahan ajar harus kita jadikan tren dalam inovasi setiap pembelajaran. Hal ini membuat guru dan siswa terasah dengan hal baru dari inovasi yang dilakukan. Guru terampil dalam berinovasi dalam bahan ajar dan siswa terasah dalam bahan ajar terbaru dan terkini. Keterbaruan dalampengembangan bahan ajar dalam rangka inovasi tetap beranjak pada kearifan lokal agar kita punya khas dan budaya tidak termakan oleh inovasi yang kita lakukan sendiri. Hal tersebut pun sudah dituangkan dalam Undang-Undang Nomor 20 Tahun 2003 tentang Sistem Pendidikan Nasional mengenai pendidikan berbasis kebudaayaan pada Bab I Pasal 1 dan Bab III Pasal 4 Ayat 1.

Pengembangan bahan ajar dengan muatan kearifan lokal tersebut penulis temukan potensi penyempurnaannya melalui kompetensi menulis deskirptif. Hal tersebut dikarenakan ditemukan bahwa beberapa bahan ajar teks deskirpsi tidak memberikan teks kearifan lokal yang sesuai bahkan tidak pernah dijumpai di tempat siswa tersebut sehingga kemungkinan salah persepesi sangat terbuka lebar dalam memahaminya. Guru harus berperan dalam kondisi bahan ajar yang demikian untuk memenuhi kearifan lokal setempat. Hanya saja banyak guru yang belum memahami mengembangkan bahan ajar tersebut sehingga guru dan siswa terkesan 'mencoba-coba' dari bahan ajar dengan kearifan lokal yang tidak ia ketahui sepenuhnya. Penelitian (Wiryanti et al., 2015) menyebutkan bahwa buku teks Bahasa Indonesia Wahana Pengetahuan yang diterbitkan oleh Kementrian Pendidikan dan Kebudayaan Republik Indonesia berisi tari saman, tari gambyong, tari kecak yang membuat tidak kontekstual pada kearifan lokal yang lain. Sebaiknya pembelajaran bahasa harus dekat dengan konteks bahasa dan budaya penggunanya. Apalagi bahasa sangat terkait dengan konteks di mana dan untuk apa itu digunakan (Risdaneva, 2018). Artinya kedekatan bahasa sangat perlu dikaitkan dengan konteks situasi yang dekat dengan penggunanya agar transfer ilmu terasa lebih mudah, lancar, cepat dan akurat. Kemudian hasil wawancara guru manyataka keterbatasan materi ajar yang ada pada buku teks. Materi ajar tentang teks deskriptif yang ada pada buku teks sangat sedikit. Hal ini tentu akan berimbas kepada kesulitan guru dan siswa dalam pembelajaran menulis teks deskripsi tersebut. Dalam pendekatan proses, menulis adalah tugas yang berat karena berlangsung dalam beberapa tahap (Karim et al., 2017).

Bentuk pembelajaran di zaman sekarang segala penerapannya mengedepankan teks. Apalagi pembelajaran menulis teks deskripsi ini, sudah jelas akan sangat berkutat pada teks. Membaca teks, memahami teks, dan sampai pada menganalisis teks. Pembelajaran dengan mengedepankan teks menstimulus siswa untuk berpikir kritis melalui masalah-masalah yang disampaikan di dalam teks sehingga terimajinasikan oleh siswa itu dalam kehidupan nyatanya. Imajinasi tadi perlu dituangkan dalam bentuk tulisan sehingga tergambar nyata dan jelas apa yang ada di dalam pikiran. Melalui Fish Bone dapat membantu membangkit ide-ide (Bilsel \& Lin, 2012). Hal inilah yang menjadi alasan bahwa siswa perlu terampil menulis teks deskripsi dalam memberikan bentuk nyata dari deskripsi yang diimajinasikannya melalui kearifan lokal yang ia ketahui bahkan ia alami melalui bantuan fishbone. Sehingga siswa lebih mudah memahami bahan ajar dengan muatan lokal tersebut dan lebih mudah juga menuliskannya kembali sebagai hasil pemahamannya terhadap bahan ajar yang ia pelajari. Bahan ajar sebaiknya berisikan tentang materi pembelajaran kontekstual yang disesuaikan dengan kehidupan nyata sehingga 
dapat membentuk atau mengonstruksi pengetahuannya sendiri (Pribadi \& Sjarif, 2010). Kontekstual yang dimaksud salah satunya ialah kearifan lokal. Kesesuain konteks melalui kearifan lokal peserta didik akan sangat membantu dalam efektifitas maupun efisiensi pembelajaran yang khas dengan budaya yang ia ketahui bahkan peserta didik alami sendiri.

\section{B. METODE}

Penelitian ini berupa analisis dari data hasil angket kebutuhan materi ajar dari siswa, guru dan ahli dalam bidang pemebalajaran Bahasa Indonesia. Metode penelitian berupa ex post facto dengan teknik analisis (Miles et al., 2018) analisis terdiri dari tiga alur kegiatan yang terjadi secara bersamaan yaitu: reduksi data, penyajian data, penarikan kesimpulan/verifikasi. Peneliti mereduksi data dengan melakukan proses pemilihan dan data kasar yang muncul dari catatan-catatan tertulis dari tanggapan siswa, guru, ahli serta bahan ajar tersebut. Bagian ini peneliti juga melakukan analisis yang menggolongkan,mengarahkan, membuang yang tidak perlu, dan mengorganisasi data dengan cara sedemikian rupa. Kemudian pada bagian penyajian data peneliti menyusun informasi dan bahasan pada setiap kelompok bagian data tersebut yang memberi kemungkinan adanya penarikan kesimpulan dan pengambilan tindakan. Terakhir peneliti menyimpulakan data-data hasil bahasan tersebut menjadi konfigurasi yang utuh. Kesimpulan-kesimpulan juga diverifikasi selama penelitian berlangsung. Sehingga didapatlah sebuah simpulan dari berbagai pandangan yang telah dipilah, dianalisis dan diverfikasi selama penelitian berlangsung. Penelitian dilakukan di Kota Dumai untuk jenjang Sekolah Menengah Pertama pada pembelajaran menulis teks deskriptif. Penulis menyebarkan angket dalam mengidentifikasi fakta lapangan untuk dijadikan dasar penelitian selanjutnya berupa pengembangan bahan ajar.

\section{PEMBAHASAN}

\section{Analisis Materi}

Analisis materi merujuk pada indikator yang telah ditetapkan sebelumnya. Bagian ini memiliki tiga indikator dengan empat belas poin pada angket sebagai acuan untuk mengidentifikasi kebutuhan guna pengembangan nantinya. Berikut ini empat belas poin indikator sebagai acuan dalam mengidentifikasi masalah guna eksplorasi kebutuhan pembelajaran dalam pengemabangan bahan ajar menulis teks deskripsi berbasis kearifan lokal melalui strategi fishbone sebagai berikut.

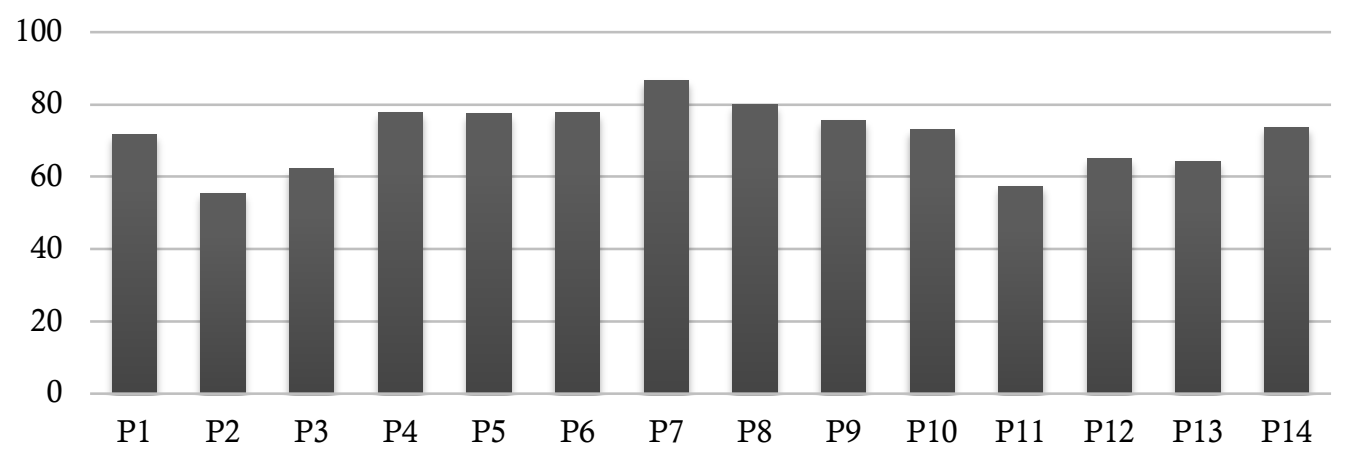

Gambar 1. Eksplorasi Kebutuhan Materi 
Setiap poin pernyataan yang diberikan peneliti kepada siswa, guru, dan ahli sebagai arahan untuk mendapatkan data yang diinginkan peneliti menggunakan kode P1 sampai dengan P14 untuk efektivitas dalam penyampaian tidak diberikan keterangan pernyataannya karena terlalu panjang untuk dimuat diartikel ini. Untuk itu keterangan tersebut sudah termasuk pada pembahasan dari data berikut ini.

P1 berupa pengalaman peserta didik dalam pembelajaran menulis teks deskripsi yang disampaikan dengan model pembelajaran yang menarik dan mudah dimengerti. Hasilnya hanya $71 \%$ dengan kateogri baik. Hal ini masih belum bisa memuaskan pengalaman belajar peserta didik karena bleum mencapai kategori sangat baik. Pangalaman yang didapatkan siswa masih tergolong kepada model pembelajaran yang biasa-biasanya saja dalam sudut pandang menarik dan mudah.

P2 pengalaman peserta didik dalam pembelajaran menulis teks deskripsi melalui strategi fishbone. Hasilnya 55\% dengan kategori kurang. Artinya hal ini masih sedikit siswa yang mengalami pembelajaran fishbone tersebut. Poin ini merupakan salah satu poin penting dalam temuan eksplorasi kebutuhan ini. Hal ini bisa menjadi dasar bahwa pengembangan melalui strategi fishbone diperlukan berdasarkan temuan tersebut.

P3 Peserta didik aktmerasa materi mengenai menulis teks deskripsi belum lengkap dan terstruktur. Hasilnya 62\% mengalami hal tersebut. Hal ini tentu merupakan hasil yang cukup sebagai dasar perlunya inovasi terhadap bahan ajar yang peserta didik dapatkan sekarang. Karena ketidaklengkapan terutama pada bagian penting seperti struktur sehingga akan berdampak buruk nanti jika pembelajaran ini terus digunakan. Adanya pengembangan menjadi harapan baru guna melengkapi materi yang telah ada.

P4 pemahaman peserta didik dalam tujuan pembelajaran teks deskripsi dan penerapannya dalam keseharian. Hasilnya 77\% pemahaman siswa punya hubungan dalam penerapan sehari-hari.

P5 penerimaan peserta didik dalam penjelasaan materi teks deskripsi secara rinci. Hasilnya 77\% dengan kategori baik. Hal ini dari segi angka ini sudah baik hanya saja ini bukan hasil yang maksimal. Hasil tersebut baru memenuhi standar saja. Kita perlu hasil yang maksimal dengan kategori sangat baik sehingga kita punya peserta didik dengan lulusan terbaik bukan hanya memenuhi standar saja. Oleh karena itu, dari hasil tersebut perlu kita capai lagi dengan meningkatkan kinerja kita melalui pengembangan inovasi bahan ajar untuk mencapai puncak kesempurnaan pengembangan materi dalam bahan ajar tersebut.

P6 keinginan peserta didik mengenai materi teks deskripsi disampaikan dengan model pembelajaran yang baru atau inovatif. Hasilnya $77 \%$ dengan kategori baik. Hal ini sudah memenuhi pembelajaran yang inovatif hanya saja belum sampai pada hasil yang sangat memuaskan. Setidaknya kita peru capai $85-95 \%$ sebagai hasil dari inovasi yang telah dilakukan.

P7 harapan peserta didik mengenai ada buku teks mengenai menulis teks deskripsi dengan materi yang lengkap. Hasilnya $86 \%$ dengan kategori sangat ingin bahan ajar yang lengkap. Hal ini juga manambah dasar untuk dilakukannya inovasi melalui pengembangan bahan ajar. Angka yang tinggi menunjukkan kebanyak peserta didik ingin adanya materi yang lebih lengkap lagi. Hal ini tidak terlapas pada kekurangan bahan ajar yang ada sekarang ini.

P8 peserta didik merasa membutuhkan lebih banyak kumpulan contoh teks deskripsi untuk inspirasi saya dalam menulis teks deskripsi. Hasilnya 80\% dengan 
kategori sangat memerlukan banyak contoh teks tersebut. Kecerdasan linguistik berupa kemampuan menggunakan kata-kata secara efektif (Gadner, 2008) dapat tercapai dengan banyaknya contoh teks yang diberikan melalui bahan ajar dalam pembelajaran. Temuan tersebut menunjukkan bahwa peserta didik kabanyakan merasa bahan ajar yang sekarang masih kurang memberikan contoh-contoh teks. Artinya perlu penambahan kembali contoh yang diinginkan peserta didik tersebut melalui inovasi pengembangan bahan ajar.

P9 Peserta didik merasa akan lebih cepat paham jika contoh-contoh teks berkaitan dengan lingkungan budaya lokal daerahnya. Hasilnya 75\% dengan kategori ingin budaya tempat peserta didik itu berasal dimuat sebagai bahan pembelajaran. Angka yang cukup besar dari antusias peserta didik dalam pemuatan budaya atau kearifan lokal sebagai bahan ajar. Hal ini sekaligus dalam melestarikan kekhasan daerah dimana peserta didik berasal. Karena bahan ajar yang khas tadilah akan memberikan daya tarik tersendiri bagi peserta didik dalam belajar sehingga ini akan memberikan dampak positif bagi kompetensi dan keterampilan yang didapatkannya.

P10 keinginan peserta didik dalam menulis teks deskripsi yang berkaitan dengan alam dan budaya yang ada di sekitar lingkungannya. Hasilnya 73\% dengan kategori tinggi. Angka tersebut membuktikan bahwa tingginya keiinginan peserta didik terhadap bahan ajar yang berkaitan dengan alam, budaya dan lingkungannya sendiri. Hal ini tentu akan mempermudahnya dalam menuliskan imajinasi yang ia dapatkan bahkan yang dialaminya sendiri. Hal tersebut dikarenakan bahan yang diambil tidak jauh dari keseharian peserta didik itu sendiri.

P11 peserta didik mengalami kesulitan dalam memahami materi teks deskripsi karena penjabaran materi yang rumit. Hasilnya 57\% mengalami kesulitan tersebut. $\mathrm{Hal}$ ini lebih dari setengah dari sampel yang ada. Tentu perlu menjadi penanganan yang serius. Materi yang rumit menjadi akar permasalahan pada poin ini sehingga hasilnya lebih dari setengah menyatakan demikian. Artinya, perlu lebih dipermudah lagi materi yang ada saat sekarang ini sehingga memberikan pembelajaran yang menyenangkan bagi siswa. Pembelajaran yang menyenangkan sebagai cikal bakal kesuksesan pembelajaran yang dilakukan. Ketika rasa nyaman sudah didapatkan oleh peserta didik dalam belajar maka pasti hasilnya sangat memuaskan.

P12 Peserta didik sering merasa kesulitan ketika ditugaskan untuk menulis sebuah teks deskripsi. Hasilnya 65\% merasa kesulitan dalam pembelajaran ini. Hal ini merupakan jumlah yang besar bahwa peserta didik mengalami kesulitan dalam pembelajaran. Peserta didik sering menghadapi masalah dalam menulis esai karena pengetahuan linguistik yang terbatas, kurangnya ide dan pemahaman yang tidak memadai mengenai struktur teks tersebut (Fareed et al., 2016). Temuan ini perlu ditangani sehingga tidak ada lagi peserta didik yang mengalami kesulitan tersebut. Perlu adanya inovasi pengembangan bahan ajar terhadap materi ini guna menjawab permasalahan tersebut. Dengan demikian, dapat memutus permasalah peserta didik dalam kesulitan belajar menulis teks deskripsi ini.

P13 Peserta didik mengalami kesulitan dalam mengembangkan tulisan yang sesuai dengan struktur teks deskripsi. Hasilnya $64 \%$ peserta didik mengalami kesulitan dalam mengembangkan tulisannya. Angka yang cukup besar dari data yang ditemukan tersebut. Hal ini membuktikan perlu adanya penanganan mengenai materi yang ada ini. Sehingga angka yang didapat dari temuan kesulitan 
ini tidak bertambah lagi nantinya. Pengembangan materi yang sederhana, dekat dengan peserta didik serta efektif diperlukan guna menunjang pembelajaran yang sempurna.

P14 kesanggupan peserta didik dapat menyusun paragraf sesuai dengan kaidah kebahasaan. Hasilnya $73 \%$ dengan kategori baik. Angka tersebut membuktikan peserta didik sudah baik dalam kaidah kebahasaan pada pembelajaran inil. Walaupun demikian, hasilnya belum memuaskan. Kita perlu capai hasil tertinggi dalam penyeajian materi berdasrkan sudut pandang kebahasaan salah satuny melalui inovasi pengembangan.

Hal yang berbeda pula penulis paparkan berdasarkan kelompok indikator dalam eksplorasi kebutuhan materi, yaitu strategi pembelajaran, kelengkapan materi dan kaidah kebahasaan sebagai berikut.

\section{a. Strategi Pembelajaran}

Hal ini sangat penting dalam keberlangsungan pembelajaran agar guru lebih mudah mengajarkannya dan siswa lebih mudah dan cepat memahaminya. Hanya saja fakta dilapangan strategi pembelajaran teks yang diterapkan tidak berjalan efektif dan efisien seperti apa yang diharapkan. Strategi pembelajaran yang biasabiasa saja membuat hasil belajar kurang memuaskan (Aini \& Sudira, 2015) Ada banyak kendala yang dihadapi guru maupun siswa dengan strategi pembelajaran yang diterapkan pada bahan ajar yang beredar di sekolah-sekolah. Mulai dari guru yang kekurangan contoh teks, guru tidak paham tahapan strategi pembelajaran dengan mengajak siswa mengamati terlebih dahulu, guru hanya tau jelaskan kemudian berikan siswa waktu untuk bertanya dan terakhir berikan tugas. Itu pun jika tidak selesai tugas tadi jadi pekerjaan rumah. Strategi kuno seperti ini masih sangat digemari oleh para guru bahkan lulusan terkini pun masih ada yang suka dengan pembelajaran seperti ini. Sehingga, hasil yang didapatkan pun kurang maksimal. Hal tersebut dapat dilihat dari hasil perhitungan analisis strategi pembelajaran sebagai bentuk eksplorasi pada materi, yaitu 3,52 dengan $70 \%$. Angka tersebut memang sudah berkategori baik tapi berdasarkan kategori yang ada hal ini perlu kita sempurnakan lagi untuk mencapai persentase 80-100. Dengan demikian, hasil eksplorasi materi pada bagian strategi pembelajaran perlu pengembangan lagi guna menyempurnakan target persentase bahan ajar tersebut.

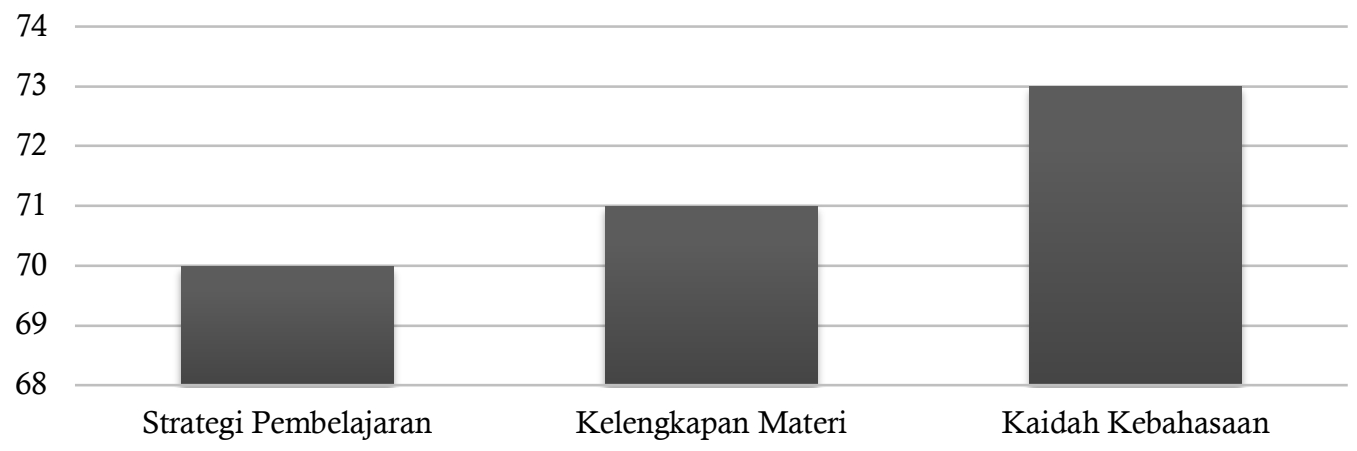

Gambar 2. Eksplorasi Kebutuhan Materi 


\section{b. Kelengkapan Materi Ajar}

Bagian ini merupakan bagian fisik yang nampak dalam bahan ajar. Oleh karena itu, akan terasa sekali bagi guru dan siswa jika ada hal yang tidak dicantumkan sebagai bentuk kelengkapan dari bahan ajar. Hal inilah yang penulis temukan berdasarkan eksplorasi kebutuhan materi dalam pemebalajaran. Mulai dari kurangnya contoh-contoh teks, arahan dalam menghubungkan antar teks dan teori struktur teks, isi teks tentang budaya yang ia belum mengetahui sepenuhnya bahkan tidak ia ketahui sama sekali, penjelasan tentang struktur dan kaidah teks yang rumit, isi teks tentang deskripsi yang rumit mengenai keadaan negara bahkan sosial politik, sampai kepada penugasan menulis yang rumit bagi siswa tersebut. Sehingga hasil yang didapatkan pun kurang maksimal. Hal tersebut dibuktikan dari hasil perhitungan analisis kelengkapan materi sebagai bentuk eksplorasi pada materi, yaitu 3,59 dengan $71 \%$. Hal ini memang sudah berkategori baik, hanya saja kita jangan berpuas diri terhadap bahan ajar ini. Karena sebaiknya bahan ajar tadi mencapai angka persentase 80-100. Perlu adanya inovasi lagi terhadap bahan ajar untuk mencapai penyempurnaan hasil yang diinginkan. Dengan demikian, hasil eksplorasi materi pada bagian kelengkapan materi ajar perlu pengembangan lagi guna menyempurnakan target persentase dalam inovasi bahan ajar.

\section{c. Kaidah Kebahasaan}

Kaidah kebahasaan pada eksplorasi materi yang penulis lakukan tidak terlalu banyak permasalahan. Aneh juga rasanya bahan ajar bahasa Indonesia yang menuntun siswa berbahasa dengan baik dan benar tetapi banyak terdapat kesalahan bahasa di dalamnya. Hal yang ditemukan hanya penyajian kalimat untuk menghubungkan teks dan arahan sebagai teori struktur dan kaidah teks tersebut. Penyajian kalimat sedikit rumit dalam menjelasakan teori teks dengan teksnya. Sehingga siswa perlu membacanya dua sampai tiga kali. Hal ini membuat pembelajaran tidak efektif karena kaidah bahasa yang rumit dalam penyajiannya. Sehingga hasil ekplorasi materi pada bagian kaidah bahasa didapatkan hasil, yaitu 3,69 dengan 73\%. Hasil tersebut berkategori baik, hanya saja bahan ajar belum mencapai tingkat maksimal kelayakan persentase, yaitu 80-100. Perlu adanya pengembangan kembali guna mencapai target bahan ajar dengan kategori sangat baik. Dengan demikian, hasil eksplorasi materi pada bagian kaidah bahasa dalam materi ajar perlu pengembangan lagi guna menyempurnakan target persentase dalam inovasi bahan ajar.

Berdasarkan hasil perhitungan keseluran poin angket tersebut didapatkan perhitungan rata-rata untuk analisis kebutuhan materi, yaitu 3,57 dengan $71 \%$. Angka tersebut menunjukkan bahwa materi yang ada sudah berkategori baik. Namun, hasilnya belum maksimal dan belum mencapai target sangat baik. Dengan demikian perlu adanya pengembangan sebagai inovasi maksimal untuk mencapai bahan ajar yang sempurna dengan kategori sangat baik.

\section{Analisis Bahan Ajar}

Analisis bahan ajar sebagai bentuk analisis secara keseluruhan yang menjadi pokok dalam penelitian ini. Hal inilah yang menjadi dasar penting untuk ditemukan sebagai hasil analisis kebutuhan yang nantinya berguna sebagai acuan pengembangan. Bahan ajar merupakan sarana untuk membantu dan mempermudah dalam kegiatan belajar mengajar sehingga terbentuk interaksi efektif 
antara peserta didik dengan pendidik, dapat meningkatkan aktivitas dan prestasi belajar peserta didik (Umbaryati, 2016). Kebutuhan bahan ajar sangat riskan dalam memenuhi kompetensi yang diharapkan. Guru terbantu dalam petunjuk yang ada di bahan ajar dan siswa secara tidak langsung difasilitasi untuk belajar mandiri melalui arahan yang ada di bahan ajar. Pembelajaran mandiri dirasa tepat dalam berorientasi pada proses menulis karena peserta didik memiliki banyak kesempatan untuk mengembangkan pengetahuan metakognitif guna kemampuan mereka sendiri, persyaratan tugas, dan strategi digunakan dalam proses menulis (Lam, 2014). Guru dan siswa sangat mengandalkan bahan ajar dalam interaksi untuk kompetensi yang akan diajarkan. Oleh karena itulah, penelitian ini dilakukan bertujuan agar interaksi terhadap kompetensi tersebut dapat dengan mudah diajarkan guru dan lebih mudah dipahami siswa. Berdasar dari permasalah tersebut, penulis menyusun angket dengan 19 poin berdasarkan 4 indikator yang telah ditentukan guna mengetahui ekslplorasi kebutuhan bahan ajar yang ada yang nantinya bisa digunakan sebagai bahan pengembangan untuk mencapai bahan ajar yang efektif dan efisien.

Setiap poin pernyataan yang diberikan peneliti kepada siswa, guru, dan ahli sebagai arahan untuk mendapatkan data yang diinginkan peneliti menggunakan kode P1 sampai dengan P19 agar efektivitas dan memudahkan pembaca dalam mehamai analisis data dengan penjelasan masing-masing sebagai berikut.

P1 Pengalaman peserta didik dalam pembelajaran menulis teks deskripsi yang disampaikan dengan model pembelajaran yang menarik dan mudah dimengerti. Hasilnya $67 \%$ dengan kategori baik. Temuan tersebut menunjukkan peserta didik sudah mendapatkan model pembelajaran yang menarik dan mudah. Walaupun begitu, angkat tersebut bukan angka yang memuaskan. Karena baru memenuhi standar saja, belum sampai kepada hasil yang sangat baik. Hal ini bisa menjadi target kita selanjutnya untuk mencapai kategori yang paling tinggi terhadap bahan ajar. Inovasi pengembangan terhadap bahan ajar mutlak diperlukan dalam mencapai target tersebut.

P2 Pengalaman peserta didik dalam pembelajaran menulis teks deskripsi melalui strategi fishbone. Hasilnya hanya 57\% saja dengan kategori kurang. Hal ini membuktikan strategi tersebut bisa kita kembangkan guna pencapaian tergaet tertinggi melalui strategi ini. Angka tersebut menunjukkan kurangnya pengalaman siswa dalam belajar dengan penerapan strategi fishbone. Adanya inovasi ini nantinya akan memberikan angka dengan hasil yang lebih tinggi lagi dari sebelumnya.

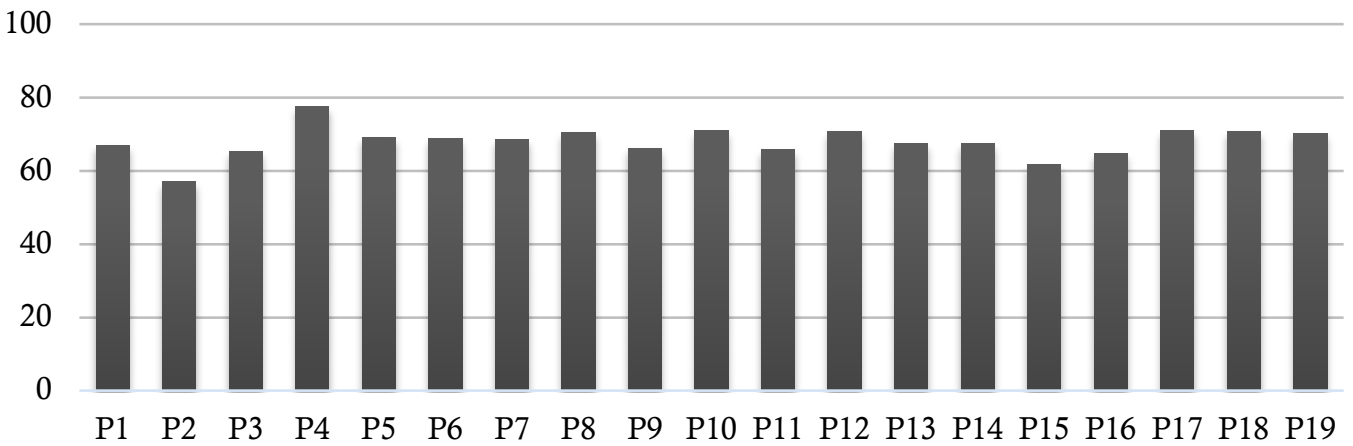

Gambar 3. Eksplorasi Kebutuhan Bahan Ajar 
P3 peserta didik merasa latihan atau tugas mengenai menulis teks deskripsi belum lengkap. Hasilnya 65\% dengan kategori cukup. Bagian ini menunjukkan bahwa peserta didik merasa latihan yang diberikan belum lengkap. Hasilnya masih berkategori cukup saja yang berarti cukup untuk memenuhi standar. Hal ini tidak boleh dibiarkan begitu saja. Perlu adanya perubahan guna peningkatan hasil jika kembali kita lakukan evaluasi seperti ini lagi. Sehingga kesalahan yang sama bisa diubah menjadi peningkatan dalam pengembangan bahan ajar untuk mempermudah peserta didik dalam belajar.

P4 peserta didik mengerjakan tugas menulis teks berdasarkan petunjuk dan soal yang ada di buku teks. Hasilnya 77\% menunjukka kategori baik. Hasil tersebut belum sampai pada kategori bahan ajar yang memuaskan. Secara angka memang sudah memenuhi standar hasil yang diinginkan tetapi karena ada hasil kategori yang lebih tinggi lagi makanya perlu kita capai. Pencapaian itu salah satu caranya melalui inovasi pengembangan bahan ajar.

P5 peserta didik mengerjakan tugas menulis teks deskripsi berdasarkan petunjuk dan soal yang ada di bahan ajar yang ditulis oleh guru Bahasa Indonesia. Hasilnya 69\% dengan kategori baik. Peserta didik pada poin ini mengikuti dengan baik petunjuk pengerjaan soal. Walaupun angka menunjukkan hanya 69\% berkategori baik, ini tidaklah cukup. Setidaknya bahan ajar pada poin ini harus dapat angka diatas $91 \%$ sebagai pencapaian sempurna sebuah pengembangan bahan ajar.

P6 peserta didik memahami urutan pengerjaan penulisan teks deskripsi yang diminta oleh guru. Hasilnya 68\% dengan kategori baik. Kategori tersebut merupakan temuan bahwa peserta didik mampu mengerjakan tulisan sesuai urutan yang diberikan. Urutan pengerjaan sebagai intruksi dari latihan guna melihat pemahaman peserta didik dari transfer ilmu yang telah dilakukan sebelumnya.

P7 peserta didik mendapat komentar kelemahan atau kekurangan dalam tulisan teks deskripsi yang saya tulis. Hasilnya 68\% dengan kategori baik. Hasil ini belum memuaskan sebagai bahan ajar yang efektif dan efisien. Peserta didik perlu mengetahui kelemahan atau kekurangannya dalam menulis teks deskirpsi tersebut. Dengan demikian, peserta didik tahu salahnya apa dan bagaimana cara memperbaikinya sehingga ia tidak mengulangi kesalahan yang sama dikemudian hari. Artinya ketika peserta didik selesai dengan tulisannya ia tidak hanay mendapatkan nilai semata saja tetapi ia juga dpat memperbaiki kesalahan dan kekurangannya juga. Hal ini baru ada peningkatan yang baik dan benar dari kompetensi peserta didik tersebut.

P8 peserta didik mengharapkan tersedianya bahan ajar menulis teks deskripsi dengan petunjuk pengerjaan yang jelas dan rinci. Hasilnya $70 \%$ dengan mengharapkan petunjuk bahan ajar yang rinci. Artinya, bahan ajar yang ada belum jelasn dan terperinci dalam memberikan arahan pengerjaan latihan atau pengamatan. Kejelasan dan kerincian petunjuk akan sangat berpengaruh pada hasil belajar peserta didik. Karena hal tersebutlah yang mengarahakan peserta didik harus diapakan latihan yang diberikan itu. Sehigga kompetensi atau keterampilan yang dimuat dalam latihan dipahami dengan baik dan tercapai oleh peserta didik.

P9 peserta didik mengaharapkan soal latihan bersifat keterampilan menulis teks deskripsi daripada yang bersifat pengetahuan. Hasilnya $66 \%$ menunjukkan lebih berharap berupa keterampilan dari pada pengetahuan. Hal ini tentu sudah jelas 
bahwa pembelajaran menulis akan lebih banyak soal tentang mengarahkan peserta didik untuk menulis atau mengembangkan tulisan. Sebagaiamana ketentuan kurikulum yang telah ditetapkan dalam keterampilan menulis.

P10 peserta didik membutuhkan latihan soal baik dari aspek pengetahuan maupun keterampilan menulis terkait materi menulis teks deskripsi. Hasilnya $71 \%$ yang artinya membutuhkan hal tersebut ada dalam bahan ajar menulis deskriptif. Pengetahuan dan keterampilan dua hal yang saling menunjang untuk memfasilitasi peserta didik dalam keterampilan menulis. Pengetahuan sebagai pengantar pemahaman dan keterampilan sebagai hasil akhir pencapaian dari peserta didik tersebut.

P11 peserta didik tertarik mengerjakan latihan di bahan ajar berupa buku dari pada di buku tulis. Hasilnya 65\% lebih berharap bahan ajar dari pada buku teks. Hal ini sudah jelas peserta didik memiliki momok tertentu dari bahan ajar yang berupa buku teks. Hal tersebut dikarenakan buku teks yang terkesan tebal, banyak, rumit, serta monoton sehingga menimbulkan ketidaknyamanan bagi peserta didik terhadap bahan ajar berupa buku teks. Hal yang berbeda dari pada bahan ajar yang lebih singkat, padat, jelas dan sederhana.

P12 peserta didik merasa membutuhkan lebih banyak kumpulan soal dan latihan untuk mreningkatkan kemampuan saya dalam menulis teks deskripsi. Hasilnya $70 \%$ peserta didik membutuhkannya. Peserta didik memiliki kecenderungan membutuhkan banyak contoh teks untuk memahami satu bentuk teks yang diajarkan. Artinya bahan ajar perlu banyak teks-teks dalam memberikan pemahaman tersebut. Buku yang disediakan memiliki contoh teks yang terbatas sehingga beberapa peserta didik merasa belum cukup pakem terhadap apa yang ajarkan. Perlu ada beberapa contoh teks lagi guna mempakemkan pengetahuan dan keterampilan yang diajarkan.

P13 peserta didik merasa akan lebih cepat paham apabila tugas dan latihan dikaitkan dengan lingkungan sekitar (budaya lokal). Hasilnya 67\% membutuhkan latihan yang berkaitan dengan budaya lokal. Hal ii membuktikan budaya lokal sangat berguna dalam pembelajaran peserta didik. Apalagi budaya tersebut diketahui sepenuhnya bahkan dialami sendiri oleh peserta didik. Dengan demikian, pembelajaran tadi adakn terasa lebih mudah untuk memahaminya karena dibantu dengan budaya lokalyang peserta didik sudah ketahui jauh sebelum pembelajaran berlangsung.

P14 sering menulis teks deskripsi dengan tema alam dan budaya lokal yang ada di lingkungan saya. Hasilnya $67 \%$ juga dibutuhkan sebagaimana poin sebelumnya. hal ini kurang lebih hampir sama dengan poin sebelumnya bahwa pembelajaran dikaitkan dengan kesaharian peserta didik itu sendiri guna mempermudah penyerapan pemahaman dan keterampilan menulisnya.

P15 peserta didik sering merasa kesulitan ketika ditugaskan untuk menulis sebuah teks deskripsi. Hasilnya $61 \%$ merasa sulit dalam menulis teks tersebut. Penugasan tersebut untuk menguji pemahaman dan keterampilan yang telah diberikan sebelumnya. kenyataannya banyak yang merasa sulit dalam menulis. Hal ini tidak terlepas dari bahan ajar yang belum maksimal dalam penulisan atau pun pengembanganya.

P16 peserta didik mengalami kesulitan dalam mengembangkan tulisan yang sesuai dengan struktur teks deskripsi. Hasilnya 64\% yang artinya banyak peserta didik yang merasa kesulitan dalam mengembangakan tulisan sesuai strukturnya. 
Artinya, bahan ajar yang diberikan kurang dipahami dengan baik mengenai penjelasan atau pun contoh teks dalam pembelajaran memahami struktur teks tersebut.

P17 peserta didik dapat menyusun paragraf sesuai dengan kaidah kebahasaan. Hasilnya $71 \%$ dapat menyusun sesuai kaidah bahasa. Hal ini memang sudah baik. Hanya saja ini bukanlah pencapaian yang terbaik. Karena dalam penilaian bahan ajar ada capaian tertinggi lagi yang bisa kita capai dalam target pengembangan, yaitu dimulai dari angka 95 keatas.

P18 Peserta didik mengharapkan ada penilaian menulis teks deskripsi yang jelas. Hasilnya $70 \%$ mengharapkan adanya penilaian teks yang jelas. Hal ini menunjukkan bahwa bahan ajar yang ada tidak memberikan penilaian teks yang jelas. Hal tersebut sangat diperlukan agar peserta didik tahu dengan sendiri kesalahan apa yang ia perbuat dan dibagian mana yang masih kurang dalam menuliskannya. Bukan hanya sekedar nilai yang ia dapat tetapi juga cara menilai yang tepat juga ia dapat dari kemandiriian penilaian yang ia dapatkan melalui penilaian teks yang terdapat dalam bahan ajar tersebut.

P19 peserta didik selalu menerima hasil penilaian teks deskripsi yang telah saya tulis. Hasilnya 70\% selalu menerima. Temuan ini membuktikan bahwa lemahnya sifat kritis peserta didik yang sebaigian besar menerima hasil penilaiannya. Sementara pada poin sebelumnya banyak peserta didik yang tidak tahu penilian yang telah ia dapatkan bagiamana dan dari mana tanpa ada dasar yang jelas.

Hal lain dari sudut pandang 4 poin penulis paparkan berdasarkan kelompok indikator dalam eksplorasi kebutuhan bahan ajar, yaitu strategi pembelajaran, ketersediaan bahan ajar, evaluasi pembelajaran dan kaidah kebahasaan sebagai berikut.

\section{a. Strategi Pembelajaran}

Analisis bahan ajar pada bagian strategi pembelajaran sebagai mana yang selalu ada dalam bahan ajar, yaitu strategi yang monoton. Strategi membaca teks, membaca struktur dan kaidah lalu mengerjakan soal. Hampir disemua kompetensi melakukan pembelajaran seperti itu. Model yang sebenarnya telah ada dari zaman dahulu tetapi dibuat sebutan yang baru sehingga terkesan adanya inovasi pembelajaran padahal secara konteksnya itu sama. Oleh karena itu, penulis dapatkan hasil eksplorasi kebutuhan dengan angka rata-rata strategi pembelajaran bahan ajar, yaitu 3,10 dengan $62 \%$. Walaupun berdasarkan kategori bahan ajar ini sudah cukup, tetapi dalam pengembangan ini belum mencapai hasil maksimal. Hal ini perlu adanya inovasi dalam bentuk pengembangan melalui strategi fishbone sebagai target kebutuhan yang diperlukan. Karena pada angket telah ditelusui bahwa strategi fishbone belum pernah diajarkan pada siswa. Dengan demikian, melalui strategi tersebut penyempurnaan pengembangan bahan ajar perlu dilakukan untuk menyempurnakan hasil sampai pada kategori sangat baik. 


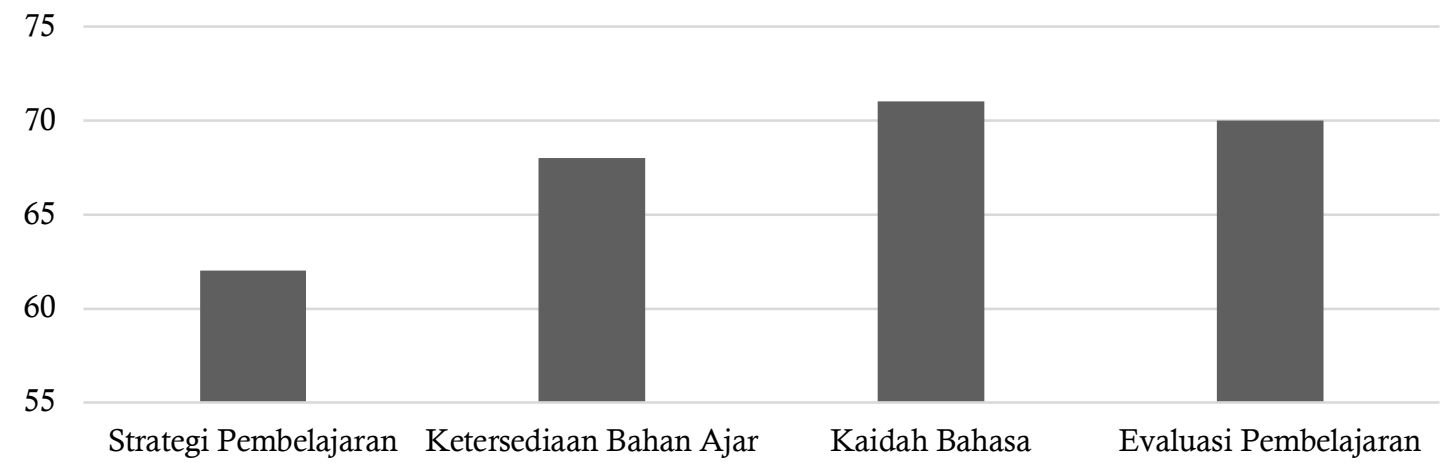

\section{Gambar 4. Eksplorasi Kebutuhan Bahan Ajar}

\section{b. Ketersedian Bahan Ajar}

Analisis ini bagian yang selalu menjadi momok dalam sebuah analisis kebutuhan guna inovasi pengembangan. Karena hampir dalam setiap penelitian pengembangan selalu inilah yang menjadi permasalahan utamanya. Hal yang sama pun penulis temukan. Terbukti bahwa dalam eksplorasi kebutuhan bahan ajar menulis deskripsi pada penelitian ini ditemukan bahwa beberapa petunjuk pengerjaan bahan ajar sedikit sulit dipahami siswa, terkadang guru harus memberikan petunjuk lagi. bahan ajar dengan budaya atau isi bahasan yang tidak sepenuhnya diketahui bahkan belum tahu sama sekali, tugas di bahan ajar yang tidak sesuai jenjang pendidikan biasnya ini selalu isi atau topik seperti hukum dimasyarakat sampai kepada deskripsi tentang keadaan dunia. Hal ini tentu akan berakibat buruk pada pencapaian yang diharapkan oleh siswa. Terbukti hasil ratarata eksplorasi kebutuhan ketersedian bahan ajar jatuh pada angka 3,41 dengan $68 \%$. Berkategori baik berdasarkan ketentuan hanya saja ini belum mencapai target maksimal. Hal inilah yang perlu kita lakukan inovasi pengembangan bahan ajar kembali guna penyempurnaan hasil yang maksimal. Dengan demikian, perlu adanya pengembangan lebih lanjut untuk mencapai hasil maksimal dengan kategori sangat baik.

\section{c. Kaidah Kebahasaan}

Eksplorasi kaidah kebahasaan yang penulis temukan dalam penelitian ini tidak banyak. Hanya ada satu permasalahan saja, yaitu beberapa siswa masih belum memahami dengan baik bagian kaidah kebahasaan dalam bahan ajar. Bahasa yang disampaikan pada bahan ajar sedikit rumit dalam menghubungkan kaidah bahasa dengan teks tersebut. Oleh karena itu, ada beberapa yang bertanya berkali-kali mengenai hal yang sama pada bagian kaidah bahasa ini. Hasil dari eksplorasi bahan ajar bagian kaidah bahasa didapatkan perhitungan rata-rata, yaitu 3,55 dengan $71 \%$. Hal ini pun jangan membuat kita cukup sampai disini karena hasilnya berkategori baik. Karena masih ada hasil dengan kategori sangat baik yang harus kita capai. Dengan demikian perlu adanya pengembangan lebih lanjut untuk menyempurnakan hasil yang telah dicapai melalui inovasi bahan ajar.

\section{d. Evaluasi di Dalam Bahan Ajar}

Evaluasi sebagai bentuk fasilitas dalam melihat pemahaman siswa terhadap apa yang telah diajarkan bahwa upaya untuk mengetahui tingkat ketercapaian 
tujuan pembelajaran adalah melalui evaluasi pembelajaran (Subyantoro, 2014). Evaluasi berupa tugas ini mampu memberikan bayangan terhadap ketercapaian pembelajaran yang telah diajarkan. Permasalahan yang ditemukan dalam penelitian ini sebagai eksplorasi kebutuhan bahan ajar hanyalah evaluasi monoton yang haya berupa pertanyaan atau penugasan tanpa adanya feedback antara bahan ajar dan siswa untuk saling berinteraksi melalui petunjuk evaluasi. Sehingga bisa diberikan muatan lokal dan penanaman karakter pada setiap evaluasi yang dikerjakan siswa. Hal ini berimbas pada hasil rata-rata eksplorasi evaluasi bahan ajar yait 3,53 dengan 70\%. Berkategori baik tetapi bukan hasil yang sangat memuaskan. Hal ini perlu kita tingkatkan lagi hasilnya menjadi kategori sangat baik dengan angka $80-100$. Dengan demikian perlu adanya pengembangan bahan ajar untuk mencapai hasil maksimal dalam penyempurnaan bahan ajar tersebut.

Berdasarkan hasil perhitungan angket secara keseluruhan pada eksplorasi kebutuhan bahan ajar dengan rata-rata nilainya 3,40 dengan 68\%. Tergolong pada kategori baik, tetapi karena ada hasil yang lebih baik lagi dari ini. Oleh karena itu, perlu kita kejar hasil yang lebih baik lagi mencapai pada kategori sangat baik. Hal tersebut dapat dicapai dengan inovasi kembali melalui pengembangan bahan ajar guna menyempurnakan hasilnya untuk mendapat hasil yang maksimal dengan kategori sangat baik. Dengan demikian, inovasi perlu dilakukan kembali agar hasil uji bahan ajar mencapai pada puncak maksimal sebuah penelitian pengembangan.

\section{PENUTUP}

Penelitian eksplorasi kebutuhan yang dilakukan ini melalui angket mendapat hasil yang baik. Hasil eksplorasi kebutuhan ini menunjukkan perlu adanya penelitian pengembangan kembali guna mencapai ketegori sangat baik dengan persentase 80-100 sebagai puncak tertinggi hasil inovasi bahan ajar. Oleh karena itu, penelitian ekplorasi kebutuhan ini menunjukkan bahwa penggunaan inovasi fishbone diperlukan dengan harapan dapat mencapi hasil tertinggi dengan kategori sangat baik.

\section{DAFTAR PUSTAKA}

Aini, S. N., \& Sudira, P. (2015). Pengaruh Strategi Pembelajaran, Gaya Belajar, Sarana Praktik, dan Media terhadap Hasil Belajar Patiseri SMK SeGerbangkertasusila. Jurnal Pendidikan Vokasi, 5(1), 88-102. https://doi.org/10.21831/jpv.v5i1.6077

Bilsel, R. U. \& Lin, D. K. J. (2012). Ishikawa Cause and Effect Diagrams Using Capture Recapture Techniques. Quality Technology \& Quantitative Management (QTQM), 9(2), 137-152. https://doi.org/10.1080/16843703.2012.11673282

Fareed, M., Ashraf, A., \& Bilal, M. (2016). ESL Learners' Writing Skills: Problems, Factors and Suggestions. Journal of Education \& Social Sciences, 4(2), 83-94. https://doi.org/10.20547/jess0421604201

Gadner, H. (2008). Multiple Intelligences. New York: Basic Books.

Karim, S. M. S., Maasum, T. N. R. T. M., \& Latif, H. (2017). Writing Challenges of Bangladeshi Tertiary Level EFL Learners. E-Bangi: Journal of Social Sciences and Humanities, 14(2), 296-306. https://ejournal.ukm.my/ebangi/article/view/20435

Lam, R. (2014). Understanding EFL Students' Development of Self-Regulated Learning in a Process-Oriented Writing Course. TESOL Journal, 6(3), 527- 
553. https://doi.org/10.1002/tesj.179

Miles, M. B., Huberman, A. M., \& Saldana, J. (2018). Qualitative data analysis: A methods sourcebook (4th ed.). California: SAGE Publications.

Pribadi, B. A., \& Sjarif, E. (2010). Pendekatan Konstruktivistik dan Pengembangan Bahan Ajar pada Sistem Pendidikan Jarak Jauh. Jurnal Pendidikan Terbuka dan Jarak Jauh, 11(2), 117-128. Retrieved from https://jurnal.ut.ac.id/index.php/jptjj/article/view/461

Risdaneva. (2018). A Critical Discourse Analysis of Women's Portrayal in News Reporting of Sexual Violence. Studies in English Language and Education (SiELE), 5(1), 126-136. https://doi.org/10.24815/siele.v5i1.9433

Subyantoro. (2014). Pengembangan Evaluasi Pembelajaran Bahasa Indonesia Berbasis Taksonomi Structure of Observed Learning Outcome. LITERA, 13(1), 6777. https://doi.org/10.21831/ltr.v13i1.1880

Umbaryati. (2016). Pentingnya LKPD pada Pendekatan Scientific Pembelajaran Matematika. Prosiding Seminar Nasional Matematika, 217-225. Retrieved from https://journal.unnes.ac.id/sju/index.php/prisma/article/view/21473

Wiryanti, N. K. D. W., Suandi, I N., \& Wisudariani, N. M. R. (2015). Pengembangan Materi Ajar Teks Deskriptif Berbasis Budaya Lokal Guna Mendukung Pembelajaran Memahami Teks Tanggapan Deskriptif Siswa Kelas VII di SMP Negeri 1 Singaraja. Jurnal Pendidikan Bahasa dan Sastra Indonesia, 3(1), 1-10. http://dx.doi.org/10.23887/jjpbs.v3i1.4980 